\title{
Mediatization of Power Corporate CEOs in Flexible Capitalism
}

\author{
Anu Kantola
}

\begin{abstract}
The present article analyses the mediatization of corporate power with a special focus on the work of the CEO. A review of the literature on the role of the media in corporate management, especially in the work of corporate leaders, shows how the techniques of power in corporate management have become mediatized. Different media have become increasingly important for the work of corporate leaders. More importantly, media have become tools of power. In flexible and soft capitalism, corporate power is exercised using performative and affective techniques aimed at identity and community formation. Consequently, different media are utilized as tools of corporate management and control. With regard to the mediatization of power, the case of corporate management suggests that one should look into the societal and institutional structures of power rather than into the power of the media.
\end{abstract}

Keywords: CEOs, mediatization, power, business media, corporate management, soft capitalism, flexible capitalism

\section{Introduction}

While there has been a growing interest in the mediatization of various institutions, the mediatization of corporate life has gained little attention. During the past decades, however, the media have become more prevalent in corporate management as corporations utilize different media to manage and control their operations and environments. In the present article, I analyse the increasing use of media in corporate management in general and focus on the work of corporate CEOs in particular.

Over recent decades, many corporate CEOs have become prevalent in the media (Ketchen et al. 2008: 529; Petrelius Karlberg 2007). Moreover, today many CEOs also carefully orchestrate their public images (Khurana 2002; Gaines-Ross 2003; Petrelius Karlberg 2007; Ketchen et al. 2008: 529). Corporate leaders have lost their facelessness and become heroic celebrities who communicate optimism, confidence and a can-do attitude (Littler 2007). They provide a symbolic pole embodying the 'soul of the company' (Garten 2001: 19). Well-known celebrity CEOs such as Bill Gates, Percy Barnevik, Akio Morita, Ingvar Kamprad, Jorma Ollila, Charles Saatchi, Anita Roddick, Steve Jobs, and Marc Zuckerberg have acquired public images reminiscent of those of entertainment celebrities.

Why is this happening? I suggest that both the media and capitalism have worked together to bring about the rise of the mediatized CEO. Different media have become instrumental in managing flexible post-Fordist corporations, which need soft manage- 
ment practices that enhance commitment, motivation, and individual identities as well as team and company cultures (Heelas 2002; Thrift 1998, 2000, 2006).

With regard to mediatization theory, I suggest that the relations between mediatization and power need to be analysed in their societal context. In corporate communications, structural changes in capitalism have been crucial forces moulding the mediatization of corporate power. Mediatization of the CEO does not imply that the power of the media is increasing, but rather highlights how the media, both mass media and new media, work as techniques of power and are increasingly used as a tool of corporate power within flexible capitalism.

\section{Mediatization of Power}

Power, as such, does not lie at the heart of mediatization theory. However, theories of mediatization often seem to suggest, at least implicitly, that the power of the media has increased in contemporary societies. As Lundby (2009: 9) suggests, old questions concerning the effect of the media and the media's influence have been addressed in new ways in mediatization theory. The strongest thesis on media logic (Altheide and Snow 1988) contends that the media transform other institutions because they need to adapt to the formats of the media (Mazzoleni 2008). A more nuanced take on this idea suggests that the impact of the media occurs in a variety of ways. For example, Schulz asserts that mediatization takes place through processes of extension, substitution, amalgamation and accommodation:

First, the media extend the natural limits of human communication capacities; second, the media substitute social activities and social institutions; third, the media amalgamate with various non-media activities in social life; and fourth, the actors and organisations of all sectors of society accommodate to the media logic (2004: 98).

Mediatization can thus be understood as a complex process involving the diffusion of different forms of reciprocal, produced and virtualized media communication (Krotz 2007; Hjarvard 2008; Hepp 2012: 69). With regard to power, this means that one must be sensitive to different forms of power and take into account different media as well as the social and cultural institutions that are involved in the mediatization process. If power is understood classically as the ability to have an impact on someone and change things, despite resistance (Lundby 2009: 9), the media could have the potential power to penetrate other institutions, which would then adapt to the requirements of the media. This conception of power, however, is also problematic with regard to the media's power. Although media logic may enter other institutions, the media seldom has coercive power. As Reichert (2009: 196, 242) suggests, words and arguments alone do not have power; they need a specific political climate to develop and become influential.

Another way of looking at the relations between the media and power is to focus on underlying relations and structures of power. One needs to look at the power relations that condition and organize media processes and content (Couldry 2003: 19; Hepp 2012: 63). As Livingstone (2009: 13) notes, such a notion of power leads to questions about how the relations and operations of power are mediated. I address this issue by examining how the rise of the mediatized CEO has been linked with societal power relations. 
I approach the mediatization of CEOs by focusing on two elements: (i) changes that have occurred in the media and (ii) changes that have taken place in corporate capitalism. As Hjarvard (2008) points out, mediatization is a double-sided process. On the one hand, the media emerge as an independent institution that more or less forces other institutions to submit to its logic. On the other hand, many other institutions increasingly use different media to perform their institutional activities. I analyse these two sides of mediatization. First, I review research that has investigated the impact of the media and journalism on corporate life. Second, I analyse the growing importance of mediated communication in corporate management and link it with the rise of 'soft' and 'fast' capitalism (Heelas 2002; Thrift 1998, 2000, 2006).

\section{Media Logic in Corporate Life}

In recent decades, the media have increasingly been focusing on the personality of the $\mathrm{CEO}$, and this media logic has become more prevalent among many corporate leaders. This change is related to changes in the media's operating systems as the number of business magazines and journalists has increased. With financial liberalization, the number of shareholders has expanded; this in turn has provided audiences for business journalism (Gaines-Ross 2003; Kjaer and Slaatta 2007; Petrelius Karlberg 2008: 12-13). Business magazines as well as economic journals have been covering industry leaders since the early twentieth century. More recently, there has been a surge in business reporting not bound by weekly or biweekly deadlines (Gaines-Ross 2003: 103, 216). Moreover, there are media outlets that work inside the business world and create publicity within it. For instance, in 2010, Barron's had a circulation of over 300,000 copies (Filbeck et al. 2012: 19). Consequently, the lives and activities of today's companies are subject to scrutiny from shareholders and the public, who require detailed information on a continuous basis (Garten 2001: 20-21).

In quantitative terms, Gaines-Ross (2003: 96-97) reported that CEO coverage in the major US national media increased by $73 \%$ between 1993 and 2002. In Europe, the coverage of CEOs in 50 selected mainstream media showed an increase of $127 \%$ over the five-year period from 1997 to 2001.

Qualitatively speaking, the media and its news criteria emphasize the personality of the leader (Petrelius Karlberg 2008: 16). The CEO is sought out as the highest authority to provide information on the firm. Because the news cycle requires short, quick answers, the CEO is singled out as personifying the company (Gaines-Ross 2003: 216; Ranft et al. 2006: 281-282). The business media, in particular, have developed story formats that celebrate corporate leaders and transform them into stars (Meindl et al. 1985; Wade et al. 2008). This can be seen most clearly in lists of 'best managers'. Business Week, for instance, has listed the 'Best Managers' on a yearly basis since 1988. Forbes has listed the 'Best-Performing CEOs' since 2001. Magazines such as Financial World, Industry Week, Chief Executive and Electronic Business annually nominate CEOs of the year. Barron's lists the 'World's Best CEOs' (Filbeck et al. 2012, 19). CEOs have also been nominated as Time magazine's 'Person of the Year' (Wade et al. 2006; Malmendier and Tate 2008: 6-8).

The formats of these stories often closely resemble those seen in lifestyle magazines, presenting star-like personalities. The US business magazines have been at the forefront 
of this development. Fortune, launched in 1930, introduced a number of new story formats such as the 'corporate story' and the history of top companies. Another more recent publication, Fast Company magazine, which was founded in 1995 and had half a million readers in 2000, presents business people in stylized formats, wearing casual or "preppy" clothes as well as traditional suits. It also maintains a readers' network, which has more than 25,000 subscribers. Here, CEOs are often depicted as iconic, heroic, transformative figures, with exceptional qualities. As Thrift concludes, the magazine is a 'cultural weapon' that aims to change the new economy's self-image and produce a new community, founded on its own stories (2000: 679).

Additionally, more critical journalists now focus on CEOs. They work against time pressures and need to cover wide subject areas; they therefore tend to possess generalist rather than specialist expertise. They might therefore have trouble grasping the complex factors that account for a firm's actions and may use familiar and simple explanations of its performance. In such situations, they often end up seeing the CEO's actions as decisive (Hayward et al. 2004: 641-642).

The personalized formats of these stories also fulfil the objectives of the business media: Portrayals of exceptional business managers, as well as competitions naming the best leaders, can be seen as the business media's own strategy for attracting audiences by personalizing the reported issues. Personalized stories create drama, which generally sells well, and they enliven dry financial facts. The figure of the CEO provides fodder for storytelling. Journalists can easily fit the CEO into the 'great man' image (Haslam et al. 2011: 2-16) of corporate success (Amernic et al. 2007; Hayward et al. 2004: 650) or failure (Gunther and Grandy 2009). Moreover, the drama is enhanced by the relatively frequent dismissals of CEOs and the nomination of new ones. Betting on CEOs is a journalistic pastime that results in increased media coverage because the replacement of a CEO can be easily moulded into a news story (Gaines-Ross 2003: 98-99). For example, in the US, a wave of mergers and acquisitions around 2000 created heightened media interest in the personalities of the CEOs when they were seen as battling over companies. As Gaines-Ross describes it:

The media dissected and inspected every detail of each CEO's leadership style and personality. We learned about their childhoods, their mother's early tutelage, their first paper routes, their coaches, their first careers, marriages and divorces (2003: 104).

The aforementioned coverage of CEOs has contributed to the creation of celebrity CEOs who have a strong media presence and like to cultivate their own reputations by appearing frequently in the media and commenting on issues that go beyond their actual everyday work (Chen and Meindl 1991; Gunther and Grandy 2009; Hayward et al. 2004). The format of the celebrity CEO is also adhered to in relation to more 'ordinary' CEOs, with the media emphasizing the exceptionality of the person and reporting on their private and personal qualities and issues. Thus, all in all, relations between CEOs and the media have been intensified. As Gaines-Ross suggests, CEOs have to become accustomed to conducting business in environments where all their deeds are on display and subject to real-time critique (2003: 217).

In terms of mediatization theory, the work of CEOs has been influenced by the media: many CEOs have had to adjust their work to the media logic. CEOs carefully control their media profiles by granting interviews at strategically planned moments, under 
the guidance of corporate communication specialists (Gaines-Ross 2003: 94; Ranft et al. 2006: 284-285). Up until the 1990s, CEOs generally had their public relations staff issue press releases if they had something to say. Now, they invite the public to get to know them, or their carefully crafted images (Gaines-Ross 2003: 101-102). Many CEOs are carefully trained to communicate effective messages and to repeat these in various emotionally appealing ways (Ranft et al. 2006: 284-285).

\section{Media in Corporate Management}

While the media have become increasingly important for many CEOs, that have at the same time become an increasingly important and integrated part of corporate management. Throughout the ages, there have been well-known business leaders with high public profiles who have built something of a personality cult within their own organizations. For instance, the 'Uncle Walt' reputation of Walt Disney has been seen as a 'deep brand' that still guides the Disney Corporation (Ranft et al. 2006: 281). The charismatic self-made entrepreneur is a classic icon of capitalism (Tjeder 2003), and direct-selling organizations, too, have been run by outgoing leaders (Biggart 1989: 115). In recent decades, however, increasing numbers of corporate CEOs have become public figures. This shift is notable compared with the earlier organized industrialism. Many earlier industrial tycoons had no interest in building a media image and the public was instead perceived as a nuisance to them (Gaines-Ross 2003: 102). In contrast, today's CEOs and their companies are pressed continuously by shareholders and the public for reams of detailed information about their lives and activities.

This change has been conditioned by the shift from industrial capitalism to flexible post-Fordist capitalism. Financial liberalization and new information technologies have turned many industries into flexible and globally dispersed network enterprises (Harvey 1990: 124, 147, 240; Castells 1996: 151-279). Businesses are decentralized into teams, which work on different continents and in different time zones on a rolling 24-hour basis, involving multiple global collaborators. Organizations and their hierarchies are often structured more loosely, with the middle layers of organizations often being outsourced (Sampson 1995; Sennett 1999 2006; Clegg 2011: 213). Today, increasingly deterritorialized corporations extend their operations across national borders, creating global connectivity (Hepp 2008; 2012: 63; Thrift 2006).

Consequently, corporate management has had to change. In times of industrial capitalism, organizations were characteristically managed by building relatively stable and hierarchical bureaucracies - the "iron cages" of Max Weber (Sennett 2006: 16-82). Conversely, the more flexible organizations are increasingly managed using techniques that are the antithesis of technological and rational cost-benefit analysis. The rise of new management practices is linked to the rise of a new "soft" and emotional capitalism (Thrift 1998; 2000; Heelas 2002; Illouz 2007; Costea, Crump and Amiridis 2008). In these dispersed and flexible structures, organizational control is increasingly concerned with discursive work that suggests organizational identities (Alvesson 2003: 207-218; Clegg and al. 2006: 312-317). Management aims to activate and intensify emotions and instil passion in its subjects (Thrift 2006: 130-152).

Many corporations are also continuously restructuring and consciously updating their corporate identities, images, reputation, and brands, which are created to gain legitimacy 
in the eyes of different stakeholders (Fombrum 1996; Dowling 2001). The range of relevant stakeholders has widened as many corporations operate in different countries and markets with diverse stakeholders. The company needs to have a favourable appearance, not only in the eyes of their customer segments, but also in the eyes of the employees, unions, suppliers, and distributors. Companies also need to communicate their aims to different normative groups such as governments, regulatory agencies, trade associations, professional societies, special interest groups, journalists, and communities (Dowling 2001: 33). Moreover, finance has internationalized and the corporations need to perform credibly in the eyes of financiers and stockholders (Davis 2013: 175-181). Especially new communication technologies such as the Internet, blogs and social media provide new platforms for global connectivity (Hepp 2008).

The shift towards more communicative, performative, and affective management practices is particularly clear in the work of the CEO, who is often, if not always, a powerful actor in any large organization (Greve and Mitsuhashi 2007). In a relatively stable industrial organization, the CEO resides at the top of the pyramid and wields power through formal hierarchies and chains of command, with middle managers playing a key role. In contrast, more flexible organizations do not utilize hierarchical supervision. In these organizations, the CEO holds a central position, and managerial strategies often rely on effective symbolic labour (Costea et al. 2008; Heelas 2002; Thrift 1998). In the dispersed organization, the CEO symbolizes the core of the company's identity (Littler 2007) and assumes a central operational role in building the company's communications (Downing 2001: 231-152). In practice, many enterprises continue to operate with many-tiered, hierarchy-based mechanistic models (Thrift 2000: 674) and combine bureaucratic control with newer soft management practices. However, power in these hybrid organizations is often concentrated at the top level of management (Courpasson 2000: 158-159; Greve and Mitsuhashi 2007; Sampson 1995: 311-314; Courpasson and Clegg 2006: 327).

As the CEO's communication efforts often play a key role in corporate organizations, corporate leaders utilize different media as tools to manage the organization. CEOs aim to effectively communicate their visions to employees (Tichy and Devanna 1986; Westley and Mintzberg 1989; Thrift 2000: 676-677). Moreover, the CEO also needs to reach out to financiers, customers, and other interest groups. For instance, a CEO may take action on troubled customer relations by apologizing for problems (Gaines-Ross 2003: 93-94). For financiers, the CEO communicates trustworthiness, and analysts place great weight on the perceived quality of a company's management (Gaines-Ross 2003: 93, 98, 215; Fombrun 1996: 64-67).

To achieve all of this, a CEO needs to develop communication strategies and CEOspeak (Amernic and Craig 2006) suited to different audiences: employees, customers, shareholders and stakeholders. Often this means well-planned communicative performances both in-house and for the mass media. A growing industry of PR professionals is employed to establish a unique corporate persona, in which every action and deed reflect in some way the values and visions the CEO wants to advance (Gaines-Ross 2003: 112). Different media, both old and new, play an important role in communicative management, as they extend the array of possible management practices of the CEO. In addition to internal chats and in-person meetings and e-mail, companies post executive speeches on their Intranets and company websites. CEOs use hard-copy memos, 
audiotapes, videotapes, webcasts, open-door sessions, online chat sessions, voicemail and mailings to the home (Gaines-Ross 2003: 131-132).

Many CEOs employ management techniques that focus on communication with people and communities (Heelas 2002: 81; Fombrun 1996: 67; Kantola 2009; Matula 2004; Alvesson and Svenigsson 2003; Trueman 1991). CEOs meet with their people and appear informal and human by addressing their audiences in familiar and relaxed ways (Edström and Jönsson 1998; Ranft et al. 2006: 283; Kantola 2009). They demonstrate their personal authenticity and create intimacy with people by disseminating biographical information (Gaines-Ross 2003: 126). In media interviews, CEOs provide details about their lives and personal philosophies, and share memories of exceptional or decisive moments. New communication technologies communicate a sense of 'filterless' communication with a 'personal touch' using direct emails, blogging, tweeting or satellite broadcasts with question-and-answer sessions (Gaines-Ross 2003: 90).

Some CEOs like to create symbolic dramas to help to overcome resistance to change and mobilize commitment to the corporate mission (Tichy and Devanna 1986). CEOs have removed Picassos from the executive dining room, eliminated chauffeur-driven cars, installed volleyball courts, shook hands with every employee or had their office doors removed. One CEO marched his senior managers across the Golden Gate Bridge wearing jackets labelled with 'Crossing the Chasm'. Another burned the employees' manual in the company's parking lot (Gaines-Ross 2003: 91-92).

All this is reminiscent of celebritization - the practice of celebrity making and production, which is increasingly applied in all areas of life (Turner 2004; Evans and Hesmondhalgh 2005; Marshall 2006; Holmes and Redmond 2012: 6). Affective appeal is at the heart of celebrity production; the celebrity must somehow embody people's sentiments and mobilize their desires (Rojek 2001: 181-199). As Marshall (1997: 203-210) suggests, press agents and public relations firms have developed expertise in identifying the affective power of the populace and in providing performances that ensure the continued power of current institutions. In the past few decades, it seems that these celebrity-making tactics have also been increasingly used in the corporate world. For instance, affective celebrity tactics often play with the tensions between a celebrity's public and private selves. The attention-grabbing public personality is spiced up with the revelation of the person's private, intimate and authentic side (Gamson 1990; Turner 2004: 8; Nunn and Biressi 2010). Similarly, many corporate leaders try to appear as exceptional figures by also revealing something of their private selves while demonstrating/adopting a personal, informal touch (Garten 2001: 148; Gaines-Ross 2003: 88-95). Emails and corporate Internet chat rooms circulate CEO folklore and story-telling in and out of the office (Ranft et al. 2006: 284-285; Gaines-Ross 2003: 127 129). CEOs become the subject of gossip and rumours that circulate, 'domesticating' them and revealing the 'real' person behind the image (Ranft et al. 2006: 283). Ikea's Ingvar Kamprad, rated as one of the richest people in the world, is known for driving an old Volvo, flying economy class, using his pensioner's discount card and buying Christmas presents during the January sales (Kantola 2009). In this way, mediatization and celebritization become intertwined (see also Driessens 2012). The techniques of celebritization have played an important role in the mediatization of the CEO and thus celebritization can be seen as a personalized form of mediatization. 


\section{The Mediatization of Corporate Power}

As the analysis above suggests, corporate management has undergone a shift from hierarchical control towards symbolic work with communicative and performative practices that aim to control identities and create meanings. Consequently, different media are increasingly used to wield managerial power in corporate life. The work of the CEO exemplifies this larger shift; the CEO is a central actor in his organization and increasingly appears in the media, utilizing various media to control and manage his organization and its environment. With the aid of new communication technologies, CEOs have developed new forms of direct, indirect, and media communication (Hepp 2012: 63-67). The different media play a role and are utilized in different ways by CEOs as they devise their communication strategies. At the same time, the media have become increasingly occupied with CEOs and increasingly focused on the personality of the $\mathrm{CEO}$. The tactics of celebrity making provide an increasingly popular alternative for a $\mathrm{CEO}$ who wants to enhance his position and manage his organization. All these changes in the work of CEOs exemplify how the exercise of power in corporate capitalism has become mediatized.

Of course, it should be pointed out that CEOs are not the only ones who use media to manage organizations. The mediatization of corporate power is a wider current as flexible corporations develop management systems that are based on symbolic work, and the work of CEOs is only one element in that change. Moreover, not all CEOs have turned into media personalities who focus on communicative work. A relatively introverted façade is common in companies for which the CEO does not need to perform in public to connect with customers or shareholders. Professional service firms such as law, accounting, investment banking, and consulting firms do not need the same level of visibility and often prefer to minimize press attention (Fombrun 1996: 160-162). Many organizations also view a CEO-centred image as a high-risk strategy and instead build cultures, identities, and visions that are independent of any individual (Dowling 2001: 55). Moreover, geographical differences exist among corporate cultures. For instance, North America places greater emphasis on the personality of the CEO than Europe does (Pollach and Kerbler 2011).

Nonetheless, the work of many CEOs demonstrates the increased mediatization of corporate power that is heavy with symbolic communicative actions. To paraphrase Schulz (2004: 98), the mediatization of the CEO has taken place through (i) extension, (ii) substitution, (iii) amalgamation and (iv) accommodation. The media have (i) extended the communication capacities of the CEO. In dispersed organizations, the media help the CEOs to reach out to their customers and markets, as well as to their employees, shareholders and stakeholders, who are often dispersed geographically. To some extent, the CEOs use media as (ii) substitutes for earlier management practices as communicative management practices have replaced, to some extent, the controlling hierarchies of supervision. Different media also appear to have been (iii) amalgamated with the exercise of power in corporate capitalism. In doing so, they have substituted some old practices in the exercise of power. Finally, CEOs and corporations have (iv) accommodated to media by carefully planning their communication strategies.

How are media utilized as techniques of power? With regard to the work of the CEOs, the mediatized power strategies work at different levels. As Meyen (2009: 16-17) notes, the mediatization works on micro-, meso- and macro-levels. At the personal micro-level, 
CEOs can use the media to gain status as exceptional individuals, worthy of exceptional rewards. Well-known CEOs have been hired to increase stock prices, enhance a firm's image and improve employee morale (Hayward et al. 2004; Ranft et al. 2006; Ketchen et al. 2008: 51). This elevated status of CEOs can be seen in the considerable increase in the material rewards of CEOs (AFL-CIO 2012; Gabaix and Landier 2008; High Pay Commission 2011; Ebert et al. 2008).

At the meso-level, in terms of organizational structure, CEOs can use their public image in order to maintain a prominent role in more flexible organizations. For a firm, a celebrity leader can become an intangible asset; a well-known CEO with a high public profile increases economic opportunities and emotional responses from employees, customers and shareholders as well as channels attention to the organization (Hayward et al. 2004; Ranft et al. 2006: 284). The CEO represents the symbolic core of the flexible company and gives a human face to a centralized power structure (Courpasson 2000). With celebrity CEOs, in particular, their reputation is expected to elevate the corporation and its prestige, power and credibility in the eyes of financiers and customers (Wade et al. 2006: 645).

At the societal macro-level, CEOs can become icons who legitimize societal power relations. The individualistic and romantic 'hagiographic profiles' of powerful CEOs can enhance the perception that the financial elite are worthy of their exalted statuses, salaries and bonuses (Haslam et al. 2011: 15).

More critically, the use of media as tools of power can also have negative consequences. The rise of the superstar CEOs has become a controversial and much-debated issue in the corporate world, as many have questioned whether celebrity CEOs are worthy of their pay and argue that their high public profiles may divert their focus from their actual work (Gunther and Grandy 2009; Ketchen et al. 2008; Khurana 2002; Malmendier and Tate 2008; Wade et al. 2006; Wade et al. 2008). CEOs may also be susceptible to hubris (Hayward et al. 2004), which can lead to overly high expectations and overcompensation (Filbeck et al. 2012: 19; Wade et al. 2008), or even to an increase in organizational corruption when leaders begin to see themselves as being a class above everyone else (Haslam et al. 2011: 15).

The focus on the CEO as an exceptional figure can also be hazardous for the organization. Many corporations are wary of the dangers of building their reputation on a single individual. It is a high risk strategy, especially in times of succession when the CEO has to be replaced (Fombrun 1996: 38-39; Dowling 2001: 55). For the employees, the notion of individual leadership may give rise to a corporate 'cult' of leadership (Tourish and Pinnington 2002).

For society at large, the public visibility of CEOs may legitimize corporate power in society (Stieglitz 2012; Crouch 2004). Over the past three decades, the share of total income going to top-income groups has increased dramatically. Atkinson, Piketty and Saez (2011: 59) suggest that the rise of superstar CEOs has played a key role in the rising incomes of top income groups in the US and the UK, where celebrity CEOs have been the most prominent, while Stieglitz (2012) sees financial elites as major contributors to the advancement of increasing inequality. Numerous studies have also discussed the harmful effects of the legitimization of inequality and of the high status of well-paid financial elites on society (Frank 1996; High Pay Commission 2011; Stieglitz 2012). 


\section{Conclusions: Media as Tools of Power}

Different media have come to play an important role in the exercise of corporate power, and the work of the CEO in particular exemplifies this shift. There have been two main sides to this change (Hjarvard 2008). For the CEOs, the media logic has become more prevalent and they need to adjust to the enhanced interest of the media, which focus on CEO personalities. At the same time, different media have become increasingly relevant for business management and have created multiple opportunities for CEOs to manage flexible and dispersed organizations.

With regard to the mediatization of power, this suggests that the media are not necessarily the leading driving force behind mediatization. Instead, the media and other institutions develop new practices through mutual and dynamic processes, and mediatization takes place within societal, political and economic structures and institutions. Instead of manifesting media power per se, the mediated performances of CEOs have become part of symbolic work that legitimizes underlying power relations at individual, organizational and societal levels (see also Couldry 2000: 4; 2003: 19; Livingstone 2009: 13).

All this also suggests a shift in the ways in which power is exercised in this reflexive phase of modernity or in high modernity (Hjarvard 2008). As Clegg noted early on, under 'post-modern', market-dominated conditions, one needs to rethink power (1989, 273-274). Discipline and coercion are not thought to be as effective as they used to be in earlier, more stable and hierarchical societies. In contrast, in more individualized societies, disciplinary and hierarchical control is replaced by affective and performative power that is increasingly about mediated communication and identity formation (Hjarvard 2009; Reichert 2009; Alexander 2011). In corporate life, corporations and their executives manage their organizations and environments through symbolic work when they create and sustain corporate cultures, identities, images, brands and reputations in the geographically dispersed and flexible organizations. In this work, various media are increasingly important instruments that cannot be neglected if one wishes to wield power effectively.

One of course needs to point out that the media do not automatically act as instruments of power - one should not make linear assumptions about media power or effects. Thus, for instance, the mass media do not go along with corporate interests and construct favourable images of the CEOs. Many CEOs receive negative coverage, and have been the subject of media scandals. Moreover, mediated CEOs' performances may fail or prove to be ineffective.

One also needs to note that the important role of the media in the exercise of power is not a totally novel development; means of communication have been used to reinforce power structures in earlier times as well. For instance, the nationally grounded mass media could be seen as tools of power in the decades after World War II in that they helped to manage mass participation and loyalty in nation states. Today, many authoritarian states use the mass media, especially national television, as tools of power.

However, there is a need for further research that analyses the techniques and symbolic tactics of soft power. How is the media utilized and interwoven with corporate management? What kinds of techniques of power have been developed, and how do they address their subjects and construct identities?

The case of superstar CEOs can also be compared with other forms of power. Most notably, political leadership and governance are turning into mediatized performances (Driessens et al. 2010). However, there are differences. For political rulers, the rise of 
performative power (Alexander 2011) largely stems from the demise of class-based parties and the increased share of floating voters. For corporate leaders, change is dictated by the globalization of corporate operations. Additionally, journalism may treat business leaders differently from politicians, business journalism perhaps being more celebratory than political journalism. There is therefore a need for research that can address the links between mediatization and power in specific contexts.

\section{References}

Alexander, J. (2011) Performance and Power. Cambridge: Polity Press.

ALF-CIO (2012) Executive paywatch. Available at: www.aflcio.org/Corporate-Watch/CEO-Pay-and-the-99/ Trends-in-CEO-Pay (Accessed 18 January 2013)

Altheide D.L., \& Snow R.P. (1988) 'Toward a theory of mediation', in Anderson, J.A. (eds.) Communication Yearbook 11 (pp.194-223). Newbury Park, CA: Sage.

Alvesson M. (2004) Knowledge Work and Knowledge-Intensive Firms. Oxford: Oxford University Press.

Alvesson M., \& Sveningsson S. (2003) 'Managers Doing Leadership: The Extra-ordinization of the Mundane', Human Relations 56(12): 1435-1459.

Amernic J., \& Craig R. (2006) CEO Speak. The Language of Corporate Leadership. Montreal: McGillQueen's University Press.

Amernic J., Craig R., \& Tourish D. (2007) 'The Transformational Leader as Pedagogue, Physician, Architect, Commander and Saint: Five Root Metaphors in Jack Welch's Letters to Stockholders of General Electric', Human Relations 60(12): 1839-1872.

Atkinson A.B., Piketty T., \& Saez E. (2011) ‘Top Incomes in the Long Run of History', Journal of Economic Literature 49(1): 3-71.

Biggart, N.W. (1989) Charismatic Capitalism. Direct Selling Organisations in America. Chicago: The University of Chicago Press.

Castells M. (1996) The Rise of the Network Society. Malden: Blackwell.

Chen C.C., \& Meindl J.R. (1991) 'The Construction of Leadership Images in the Popular Press: The Case of Donald Burr and People Express', Administrative Science Quarterly 36(4): 521-552.

Clegg S. (1989) Frameworks of Power. London: Sage.

Clegg S., Courpasson D., \& Phillips N. (2006) Power and Organisations. London: Sage.

Costea B., Crump N., \& Amiridis K. (2008) Managerialism, the Therapeutic Habitus and the Self in Contemporary Organizing', Human Relations 61(5): 661-685.

Clegg S. (2011) Under reconstruction: Modern bureaucracies', in Clegg S., Harris M. and Höpfl, H. (eds.) Managing Modernity. Beyond Bureaucracy? (pp. 202-29), Oxford: Oxford University Press,

Couldry N. (2000) The Place of Media Power: Pilgrims and Witnesses of the Media Age. London: Routledge.

Couldry N. (2003) Media Rituals: A Critical Approach. London: Routledge.

Courpasson D. (2000) 'Managerial Strategies of Domination: Power in Soft Bureaucracies', Organisation Studies 21: 141-160.

Courpasson, D., \& Clegg S. (2006) 'Dissolving the Iron Cages? Tocqueville, Michels, Bureaucracy and the Perpetuation of Elite Power', Organisation 13(3): 319-343.

Crouch, C. (2004) Post-Democracy. Cambridge: Polity Press.

Davis, A. (2013) Promotional Cultures. The Rise and Spread of Advertising, Public Relations, Marketing and Branding. Cambridge: Polity Press.

Dowling, G. (2001) Creating Corporate Reputations: Identity, Image and Performance. Oxford: Oxford University Press.

Driessens, O. (2012) 'The Celebritization of Society and Culture: Understanding the Structural Dynamics of Celebrity Culture', International Journal of Cultural Studies. September 18, 201210. (Accessed 18 January 2013)

Driessens, O., Raeymaeckers, K., Verstaeten, H., \& Vanderbussche S. (2010) 'Personalization According to Politicians: A Practice Theoretical Analysis of Mediatization', Communications 35: 309-326.

Ebert, F., Torres, R., \& Papadakis, K. (2008) Executive Compensation: Trends and Policy Issues. International Institute for Labour Studies. Discussion Paper 190/2008.

Edström, A, \& Jönsson, S. (1998) Svensk ledarskap, in Czarniawska, B. (ed.) Organisations teori på svenska (pp.149-171), Malmö: Liber Ekonomi.

Evans, J., Hesmondhalgh, D. (2005) Understanding Media: Inside Celebrity. Maidenhead: Open University Press. 
Fillbeck, G, Gorman, R., \& Zhao, X. (2012) 'Barron's Survey: The World's Best CEOs', Accounting and Finance Research 1(1): 18-37.

Fombrun, C. (1996) Realizing Value from the Corporate Image. Boston: Harvard Business School Press.

Frank, R. (1996) The Winner-Take-All Society: Why the Few at the Top Get So Much More Than the Rest of Us. New York: Penguin.

Gabaix, X., \& Landier, A. (2008) 'Why Has CEO Pay Increased So Much?', The Quarterly Journal of Economics, 123 (1): 49-100.

Gaines-Ross, L (2003) CEO Capital. A Guide to Building CEO Reputation and Company Success. Hoboken, New Jersey: John Wiley.

Gamson, J. (1994) Claims to Fame: Celebrity in Contemporary America. Berkeley: University of California Press.

Garten, J. (2001) The Mind of the CEO. London: Penguin Books.

Greve, H.R., \& Mitsuhashi, H. (2007) Power and Glory: Concentrated Power in Top Management Teams. Organisation Studies 28: 1197-1220.

Gunther, M.P., \& Grandy, G. (2009) 'The Media’s Construction of CEO Infamy', Journal of Strategic Management 2(4): 300-328.

Harvey, D. (1990) The Condition of Postmodernity: An Enquiry into the Origins of Cultural Change. Cambridge, MA: Blackwell,

Haslam, S.A., Reicher, S., \& Platow, M.J. (2011) The New Psychology of Leadership: Identity, Influence and Power. New York: Taylor and Francis Group.

Hayward, M.L.A., Rindova, V.P., \& Pollock, T.G. (2004) 'Believing One’s Own Press: The Causes and Consequences of CEO Celebrity', Strategic Management Journal 25(7): 637-653.

Heelas., P. (2002) 'Work ethics, soft capitalism and the "turn to life"', in du Gay P. and Pryke M. (eds.) Cultural Economy (pp.78-96). London: Sage.

Hepp, A. (2008) 'Translocal media cultures: Networks of the media and globalization', in Hepp, A., Krotz, F., Moores, S. and Winter C. (eds) Connectivity, Networks and Flows: Conceptualizing Contemporary Communications, Cresskill, New Jersey: Hampton Press.

Hepp, A. (2012) Cultures of Mediatization. Cambridge: Polity Press.

High Pay Commission (2011) Cheques With Balances: Why Tackling High Pay is in the National Interest. The Final Report of the High Pay Commission. Available at: http://highpaycommission.co.uk/wpcontent/ uploads/2011/11/HPC_final_report_WEB.pdf (Accessed 18 January 2013)

Hjarvard, S (2008) The Mediatization of Society. A Theory of the Media as Agents of Social and Cultural Change. Nordicom Review 29 (2): 105-134.

Hjarvard, S. (2009) 'Soft individualism: Media and the changing social character', in Lundby K. (ed.) Mediatization. Concept, Changes, Consequences (pp.159-178), New York: Peter Lang.

Holmes, S., \& Redmond, S. (2012) 'A Journal in Celebrity Studies', Celebrity Studies 1(1): 1-10.

Illouz, E. (2007) Cold Intimacies: The Making of Emotional Capitalism. Cambridge: Polity Press.

Kantola, A. (2009) The rise of charismatic authority styles in corporate capitalism. Journal of Power 2(3): 423-440.

Ketchen, D., Adams, G., \& Shook, C. (2008) 'Understanding and Managing CEO Celebrity', Business Horizons 51: 529-534.

Khurana, R. (2002) 'The Curse of the Superstar CEO', Harvard Business Review, September 2002: 2-8.

Kjaer, P., \& Slaatta, T. (eds.) (2007) Mediating Business: The Expansion of Business Journalism. Copenhagen: Copenhagen Business School Press.

Krotz, F. (2007) 'The Meta-process of 'Mediatization' as a Conceptual Frame', Global Media and Communication 3: 256-260.

Lee, B., \& LiPuma, E. (2002) 'Cultures of Circulation: The Imaginations of Modernity', Public Culture 14(1): 191-214.

Littler, J. (2007) 'Celebrity CEOs and the cultural economy of tabloid intimacy', in Redmond, S. and Holmes, S. (eds.) Stardom and Celebrity (pp.230-243). London: Sage.

Livingstone, S. (2009) 'On the Mediation of Everything: ICA Presidential Address 2008', Journal of Communication, 59 (1): 1-18.

Lundby, K. (2009) 'Introduction: "Mediatization” as key', in Lundby, K. (ed.) Mediatization. Concept, Changes, Consequences (pp.1-20), New York: Peter Lang.

Malmendier, U., \& Tate, G. (2008) Superstar CEOs. National Bureau of Economic Research. Working paper 14140 .

Marshall, D. (1997) Celebrity and Power. Fame in Contemporary Culture. Minneapolis: University of Minnesota Press.

Marshall, D. (2006) The Celebrity Culture Reader. New York: Routledge.

Matula, J.J. (1984) 'Learning to Lead by Strolling Around', Executive Educator 6(7), 20. 
Mazzoleni, G. (2008) 'Media logic', in Donsbach, W. (ed.) The International Encyclopedia of Communication VII (pp. 2930-2932), City: Publisher.

Meindl, J.R., Ehrlich, S.B., \& Dukerich, J.M. (1985) 'The Romance of Leadership', Administrative Science Quarterly 30: 78-102.

Meyen, M. (2009) 'Medialisierung. Medien andKommunikationswissenschaft', Journal 57 (1): .23-38. Available at:http://mediacultureonline.de/fileadmin/bibliothek/meyen_medialisierung/meyen_medialisierung. pdf (Accessed 18 January 2013)

Nunn, H., \& Biressi, A. (2010) “"A Trust Betrayed”: Celebrity and the Work of emotion', Celebrity Studies 1(1): 49-64.

Petrelius Karlberg, P. (2008) Den Medialiserade Direktören. PhD Thesis, Handelhögskolan, Stockholm. Stockholm: Ekonomiska forsniingsinstitutet vid Handelhögskolan i Stockholm.

Pollach, I., \& Kerbler, E. (2011) 'Appearing Competent. A Study of Impression Management in US and European CEO Profiles’, Journal of Business Communication 48(4): 355-372.

Ranft, A., Ferris, G., Zinko, R., \& Buckley, M.R. (2006) 'The Costs and Benefits of CEO Reputation', Organisational Dynamics 35(3): 279-290.

Reichert, J. (2009) Kommunikationsmacht. Was isKommunication und was wermagsie? Und weshalbvermagsie das? Wiesbaden: VS VerlagfürSozialwissenschaften.

Rojek, C. (2001) Celebrity. London: Reaktion Books.

Sampson, A. (1995) The Company Man: The Rise and Fall of Corporate Life. New York: Times Books/ Random House.

Schröter, H.G. (2005) Americanization of the European Economy. Dordrecht: Springer.

Schulz, W. (2004) 'Reconstructing Mediatization as an Analytical Concept', European Journal of Communication 1: 87-101

Sennett, R. (1999) The Corrosion of Character. London: W.W. Norton.

Sennett, R. (2006) The Culture of the New Capitalism. New Haven: Yale University Press.

Stieglitz, J. (2012) The Price of Inequality: How Today's Divided Society Endangers Our Future. New York: W.W. Norton.

Thrift, N. (1998) 'The rise of soft capitalism', in Herod, A., Tuathail, G. and Roberts, S.M. (eds.) An Unruly World? Globalization, Governance and Geography (pp. 25-71), London: Routledge.

Thrift, N. (2000) 'Performing Cultures in the New Economy', Annals of the Association of American Geographers 90(4): 674-692.

Thrift, N. (2006) Knowing Capitalism. London: Sage.

Tichy, N., \& Devanna, M.A. (1986) The Transformational Leader. The Key to Global Competitiveness. New York: John Wiley.

Tjeder, D. (2003) The Power of Character. Middle-class masculinities, 1800-1900. Stockholm: Författaresbokmaskin.

Trueman, W. (1991) 'CEO Isolation and How to Fight It', Canadian Business 64 (7), 28-32.

Turner, G. (2004) Understanding Celebrity. London: Sage.

Turner, G. (2012) 'Approaching Celebrity Studies', Celebrity Studies 1(1): 11-20.

Wade, J.B., Porac, J.F., Pollock, T.G., \& Graffin, S.D. (2006) 'The Burden of Celebrity: The Impact of CEO Certification Contests on CEO Pay and Performance', Academy of Management Journal 49(4): 643-660.

Wade, J.B., Porac, J.F., Pollock, T.G., \& Graffin, S.D. (2008) 'Star CEO: Benefit or Burden? Organisational Dynamics 37(2): 203-210.

Westley, F.R., \& Mintzberg, H. (1989) 'Visionary Leadership and Strategic Management', Strategic Management Journal 10: 17-32.

ANU KANTOLA, Docent, University Lecturer, Department of Social Research / Media and Communication Studies, University of Helsinki, anu.kantola@helsinki.fi 